\title{
Effects of salt stress on plant growth, stomatal response and solute accumulation of different maize genotypes
}

\author{
André Dias de Azevedo Neto ${ }^{1}$, José Tarquinio Prisco ${ }^{2}$, Joaquim Enéas-Filho², Claudivan Feitosa de Lacerda ${ }^{2}$, \\ José Vieira Silva ${ }^{2}$, Paulo Henrique Alves da Costa $^{2}$ and Enéas Gomes-Filho ${ }^{2 *}$
}

${ }^{1}$ Departamento de Biologia, Universidade Federal Rural de Pernambuco, CEP 52171-900, Recife, PE, Brasil; ${ }^{2}$ Departamento de Bioquímica e Biologia Molecular, Universidade Federal do Ceará, CP 6039, CEP 60455-900, Fortaleza, CE, Brasil; *Corresponding author: egomesf@ufc.br Received:20/10/2003, Accepted: 06/01/2004

Seeds from eight different maize genotypes (BR3123, BR5004, BR5011, BR5026, BR5033, CMS50, D766 and ICI8447) were sown in vermiculite, and after germination they were transplanted into nutrient solution or nutrient solution containing $100 \mathrm{mmol} . \mathrm{L}^{-1}$ of $\mathrm{NaCl}$ and placed in a greenhouse. During the experimental period plant growth (dry matter, shoot to root dry mass ratio, leaf area, relative growth rate, and net assimilation rate), leaf temperature, stomatal conductance, transpiration, predawn water potential, sodium, potassium, soluble amino acids and soluble carbohydrate contents were determined in both control and salt stressed plants of all genotypes studied. Salt stress reduced plant growth of all genotypes but the genotypes BR5033 and BR5011 were characterized as the most salt-tolerant and salt-sensitive, respectively. Stomatal response of the salt-tolerant genotype was not affected by salinity. Among the studied parameters, shoot to root dry mass ratio, leaf sodium content and leaf soluble organic solute content showed no relation with salt tolerance, i.e., they could not be considered as good morpho-physiological markers for maize salt tolerance. In contrast, sodium and soluble organic solutes accumulation in the roots as a result of salt stress appeared to play an important role in the acclimation to salt stress of the maize genotypes studied, suggesting that they could be used as physiological markers during the screening for salt tolerance.

Keywords: growth analysis; osmoregulation; salinity; transpiration; Zea mays, water relations;.

Efeito do estresse salino sobre o crescimento, resposta estomática e acúmulo de solutos em diferentes genótipos de milho: Sementes de oito genótipos de milho (BR3123, BR5004, BR5011, BR5026, BR5033, CMS50, D766 e ICI8447) foram semeadas em vermiculita e, após a germinação, transplantadas para vasos contendo solução nutritiva ou solução nutritiva com 100 mmol.L $\mathrm{L}^{-1} \mathrm{de} \mathrm{NaCl}$, em casa de vegetação. Durante o período experimental avaliaram-se, em plantas de todos os genótipos, sob condições de controle e estresse salino, os seguintes parâmetros: crescimento (matéria seca, relação de matéria seca parte aérea/raiz, área foliar, taxa de crescimento relativo e taxa de assimilação líquida), temperatura foliar, condutância estomática, transpiração, potencial hídrico antemanhã e teores de sódio, potássio, aminoácidos solúveis e carboidratos solúveis. O estresse salino reduziu o crescimento das plantas de todos os genótipos, sendo o BR5033 e o BR5011 caracterizados como tolerante e sensível ao estresse salino respectivamente. A resposta estomática do genótipo tolerante não foi influenciada pela salinidade. Entre os parâmetros estudados, a relação de matéria seca parte aérea/raiz e os teores de sódio e de solutos orgânicos nas folhas não mostraram relação com a tolerância à salinidade, isto é, não foram considerados bons marcadores morfo-fisiológicos para a tolerância à salinidade em milho. Em contraste, os teores de sódio e de solutos orgânicos nas raízes mostraram desempenhar um importante papel na aclimatação dos genótipos estudados ao estresse salino, sugerindo que eles poderiam ser usados como marcadores fisiológicos durante a seleção para tolerância à salinidade.

Palavras-chave: análise de crescimento, osmorregulação, relações hídricas, salinidade, transpiração, Zea mays.

\section{INTRODUCTION}

Soil salinization is one of the major factors of soil degradation. It has reached $19.5 \%$ of the irrigated land and $2.1 \%$ of the dry-land agriculture existing on the globe (FAO,
2000). Salinity effects are more conspicuous in arid and semiarid areas where $25 \%$ of the irrigated land is affected by salts. Considering that $52 \%$ of northeast Brazil is within semiarid tropics (Lira et al., 1982) and the increase of salt-affected 
soils due to poor soil and water management in the irrigated areas, the salinity problem became of great importance for agriculture production in this region.

Salinity inhibition of plant growth is the result of osmotic and ionic effects and the different plant species have developed different mechanisms to cope with these effects (Munns, 2002). The osmotic adjustment, i. e., reduction of cellular osmotic potential by net solute accumulation, has been considered an important mechanism to salt and drought tolerance in plants. This reduction in osmotic potential in salt stressed plants can be a result of inorganic ion $\left(\mathrm{Na}^{+}, \mathrm{Cl}^{-}\right.$, and $\mathrm{K}^{+}$) and compatible organic solute (soluble carbohydrates, amino acids, proline, betaines, etc) accumulations (Hasegawa et al., 2000). The osmotic adjustment in both roots and leaves contribute to the maintenance of water uptake and cell turgor, allowing physiological processes, such as stomatal opening, photosynthesis, and cell expansion (Serraj and Sinclair, 2002). In addition to their role in cell water relations, organic solute accumulation may also help towards the maintenance of ionic homeostasis and of the $\mathrm{C} / \mathrm{N}$ ratio, removal of free radicals, and stabilization of macromolecules and organelles, such as proteins, protein complexes and membranes (Bohnert and Shen, 1999, Bray et al., 2000). These solutes may also help towards the control of $\mathrm{pH}$ in the cytosol and detoxification of excess $\mathrm{NH}_{4}^{+}$(Gilbert et al., 1998).

Although the relationship between osmoregulation and salt tolerance is not clear, there is evidence that the osmotic adjustment appears, at least partially, to be involved in the salt tolerance of certain plant genotypes (Richardson and McCree, 1985). Therefore, the objective of this investigation was to evaluate the effects of salt stress on growth, water relations and gas exchange of different maize genotypes, commonly grown in northeast Brazil, and at the same time try to correlate these effects with changes in ionic and organic solute accumulation, with a view to a better understanding of the mechanisms of salt tolerance in these genotypes.

\section{MATERIALS AND METHODS}

Growth condition and treatments: seeds of eight different maize (Zea mays, L.) genotypes (five cultivars: BR5004, BR5011, BR5026, BR5033 and CMS50, two triple hybrids: BR3123 and ICI8447, and one simple hybrid: D766) used in northeast Brazil (Azevedo Neto and Tabosa, 1999), were obtained from the Empresa Pernambucana de Pesquisa Agropecuária (IPA), Recife, PE, Brazil. They were sown in trays containing vermiculite, watered daily and kept in a greenhouse. Five days from seedling emergence they were transferred to trays containing half-strength Hoagland's nutrient solution, and eight days later they were transferred to plastic pots containing $3 \mathrm{~L}$ of full strength nutrient solution (control treatment) or nutrient solution to which 100 mmol. $\mathrm{L}^{-1}$ of $\mathrm{NaCl}$ was added (salt stress treatment). Salt additions (25 mmol. $\mathrm{L}^{-1} \mathrm{NaCl}$ per day) started at the time of transplantation into the plastic pots, and the plants from both treatments were grown under the same conditions for $15 \mathrm{~d}$ (end of the experimental period).

Growth analysis: at the end of the experimental period plants from both treatments were harvested, separated into roots, stem + leaf sheath, and leaf blade, for fresh and dry mass determinations as well as leaf area measurements. Dry mass (DM) was determined after drying the plant parts in an oven at $65^{\circ} \mathrm{C}$ for $72 \mathrm{~h}$, and leaf area (LA) was measured with a LI3000 leaf area meter (LI-COR, Inc. Lincoln, NE, USA). Growth analysis was evaluated according to Benincasa (1988), and the relative growth rate (RGR) and the net assimilation rate (NAR) determined as follows:

$$
\begin{aligned}
& \mathrm{RGR}=\left(\ln \mathrm{DM}_{2}-\ln \mathrm{DM}_{1}\right)\left(\mathrm{t}_{2}-\mathrm{t}_{1}\right)^{-1} \quad\left(\mathrm{~g} \cdot \mathrm{g}^{-1} \cdot \mathrm{d}^{-1}\right) \\
& \mathrm{NAR}=\left[\left(\mathrm{DM}_{2}-\mathrm{DM}_{1}\right)\left(\mathrm{LA}_{2}-\mathrm{LA}_{1}\right)^{-1}\right]\left[\left(\ln \mathrm{LA}_{2}-\ln \mathrm{LA}_{1}\right)\left(\mathrm{t}_{2}-\mathrm{t}_{1}\right)^{-1}\right] \\
& \left(\mathrm{g} \cdot \mathrm{m}^{-2} \cdot \mathrm{d}^{-1}\right) \text { where }
\end{aligned}
$$

$\mathrm{DM}_{1}$ is the initial total (shoot + root) dry mass, $\mathrm{DM}_{2}$ the final total dry mass, $\mathrm{LA}_{1}$ the initial leaf area, $\mathrm{LA}_{2}$ the final leaf area, and $\left(t_{2}-t_{1}\right)$ the difference in time interval between the two samplings (15 d).

Transpiration, stomatal conductance, leaf temperature and leaf water potential: measurements of leaf temperature $\left(\mathrm{T}_{l}\right)$, stomatal conductance $\left(\mathrm{g}_{\mathrm{s}}\right.$ ) and transpiration $(\mathrm{E})$ were made on the median portion of the youngest fully expanded leaf, one day prior to plant sampling, at 8-9 a.m. Photosynthetic active radiation (PAR) during the measurements ranged from 900 to $1100 \mu \mathrm{mol} \cdot \mathrm{m}^{-2} \cdot \mathrm{sec}^{-1}$. A steady-state porometer, model LI-1600 (LI-COR, Inc. Lincoln, NE, USA) was used for the measurements. At the sampling date, the same leaves used for the above determinations were utilized for predawn leaf water potential $\left(\Psi_{\mathrm{w}}\right)$ measurements, using a model 3035 pressure chamber (Soil Moisture Equipment Corp, Santa Barbara, CA, USA).

$\mathrm{Na}^{+}, \mathrm{K}^{+}$, amino acid and soluble carbohydrate contents: the extract used for determination of ions and soluble carbohydrate contents was prepared by grinding $100 \mathrm{mg}$ of 
dry tissue with $10 \mathrm{~mL}$ of distilled deionized water at $25^{\circ} \mathrm{C}$ for $1 \mathrm{~h}$, centrifuging this material at $3,000 \mathrm{~g}_{\mathrm{n}}$ for $5 \mathrm{~min}$, and then filtering the supernatant through qualitative filter paper. An aliquot of this filtrate was used for $\mathrm{Na}^{+}$and $\mathrm{K}^{+}$determinations by flame photometry (Sarruge and Haag, 1974) and another for soluble carbohydrates determination according to Dubois et al. (1956), using $\mathrm{D}(+)$-glucose as standard. The rest of this aqueous extract was further used for soluble amino acid extraction and determination.

For free amino acid determination, $0.5 \mathrm{~mL}$ of $10 \%$ trichloroacetic acid was added to an aliquot of $0.5 \mathrm{~mL}$ of the water extract and the mixture was kept at $25^{\circ} \mathrm{C}$ for $1 \mathrm{~h}$. This mixture was then centrifuged at $12,000 g_{\mathrm{n}}$ for $5 \mathrm{~min}$, and the supernatant used for amino acid determination (Yemm and Cocking, 1955), using L-leucine as standard.

Experimental design and statistical analysis: the experimental design was a completely randomized factorial eight (genotypes) $\mathrm{x}$ two (salt levels) with three replicates. The means and their standard deviations or the Tukey test were used for comparing different treatments, and the coefficient of correlation (r) and the F-test were used for studying correlation between variables (Snedecor, 1956).

\section{RESULTS}

Growth analysis: salt stress reduced dry masses of both shoot (SDM) and root (RDM) of all maize genotypes, except RDM of genotype BR5033, which was not affected by salinity (figure 1). When subjected to salt stress, genotype BR5011 showed the largest SDM and RDM reductions (66.5 and $61.4 \%$, respectively) while genotype BR5033 showed a $33.8 \%$ reduction in SDM and a lack of reduction in RDM. Salt stress did not affect SDM/RDM of genotypes BR3123, BR5004, BR5011 and ICI8447, but decreased the ratios for genotypes BR5026, BR5033, CMS50, and D766. In general, leaf area (LA), relative growth rate (RGR), and net assimilation rate (NAR) followed the same pattern as SDM, i. e., all genotypes had their LA, RGR and NAR inhibited by salt stress.

Transpiration and leaf water potential: five of the eight genotypes (BR3123, BR5004, BR5011, BR5026 and ICI8447) showed a higher leaf temperature $\left(\mathrm{T}_{l}\right)$ under salt stress than in the control treatment, and three of them (BR5033, CMS50 and D766) showed no difference in $\mathrm{T}_{l}$, when subjected to salt stress (table 1). Stomatal conductance $\left(\mathrm{g}_{\mathrm{s}}\right)$, transpiration (E) and predawn leaf water potential $\left(\Psi_{\mathrm{w}}\right)$ decreased when the plants were subjected to salt stress, except for BR5033 which was unaffected.
$\mathrm{Na}^{+}, \mathrm{K}^{+}$, amino acid and soluble carbohydrate contents: the $\mathrm{Na}^{+}$content was higher in roots than in leaves of all genotypes studied in both control and salt stressed plants (figure 2). Although $\mathrm{Na}^{+}$content of salt stressed plants was higher in roots, the increase of this ion as a result of salt stress was more pronounced in leaves than in roots. Genotypes BR5004, BR5011, BR5026, BR5033, CMS50 and ICI8447 showed the highest $\mathrm{Na}^{+}$contents in leaves of salt stressed plants, while BR3123 and D766 presented the lowest values. Although BR5004, BR5011, BR5026, BR5033 and CMS50 have shown the same $\mathrm{Na}^{+}$content in leaves, BR5011 and BR5026 were the only genotypes to present leaf ion toxicity symptoms. When root $\mathrm{Na}^{+}$content of salt stressed plants was analyzed, BR3123, BR5004, BR5033, CMS50, D766, and ICI8447 showed the highest $\mathrm{Na}^{+}$accumulations and BR5011 and BR5004 presented the lowest. BR5033 accumulated 26.4\% more $\mathrm{Na}^{+}$in roots than BR5011.

Potassium in leaves was reduced as a result of salt stress for all genotypes, but the same did not happen for roots of the genotypes BR5004, BR5026 and BR5033 (figure 2). The genotype BR5011 showed a $31.6 \%$ reduction in root $\mathrm{K}^{+}$as a result of salt stress while the BR5033 showed no significant reduction.

Salt stress increased the content of soluble amino acids in leaves from all genotypes studied and the highest increase (113\%) occurred in genotype BR5033 (figure 2). However, the only genotype that showed an increase in root amino acids was BR5033. Leaf and root soluble carbohydrates for most genotypes decreased or stayed constant as a result of salt stress, except genotype BR5033 which showed a 14\% increase in leaves. The apparent increases in root soluble carbohydrates observed in BR5033 and CMS50 were not statistically significant. When root amino acids and root carbohydrates from salt stressed plants in both BR5011 and BR5033 genotypes were compared, it was observed that the latter had $132 \%$ more amino acids and $122 \%$ more carbohydrates than the former.

Plant growth, solute accumulation and predawn leaf water potential relationships: comparing leaf and root amino acid and carbohydrate contents with RGR and NAR of salt stressed plants, it was observed that there was no statistically significant correlation between amino acids or carbohydrates in leaves with growth (data not shown). However, there were highly significant correlations between soluble organic solutes in the roots and these growth parameters (figure 3). When analyzing the different genotypes it was observed that genotype BR5011 always had the lowest values of RGR and NAR. It also accumulated the least amount of soluble organic 
solutes in the roots. In contrast, genotype BR5033 accumulated the highest amount of soluble organic solutes and its RGR and NAR were always close to maximal.

\section{DISCUSSION}

Plant growth (SDM, RDM, LA, RGR, and NAR) of all genotypes studied were inhibited by salt stress. Genotype BR5011 suffered the largest growth reduction while the smallest reduction was observed for genotype BR5033, suggesting that the former is the most salt-sensitive and the latter the most salt-tolerant (figure 1).
Although several authors have suggested that the reduction in SDM/RDM ratio due to water shortage should be an indicator of stress adaptation, and consequently a good morpho-physiological marker for stress tolerance (Alberico and Cramer, 1993; Azevedo Neto and Tabosa, 2000a), our data do not support this idea because the genotypes BR5026 and D766, that were among the more salt-sensitive also showed significant decreases in SDM/RDM ratio.

There was a relation between NAR reduction and growth inhibition for most of the genotypes as a result of salt stress. Similar results were also obtained by others (Erdei and Taleisnik, 1993; Alarcon et al., 1994; Wahid et al., 1999),

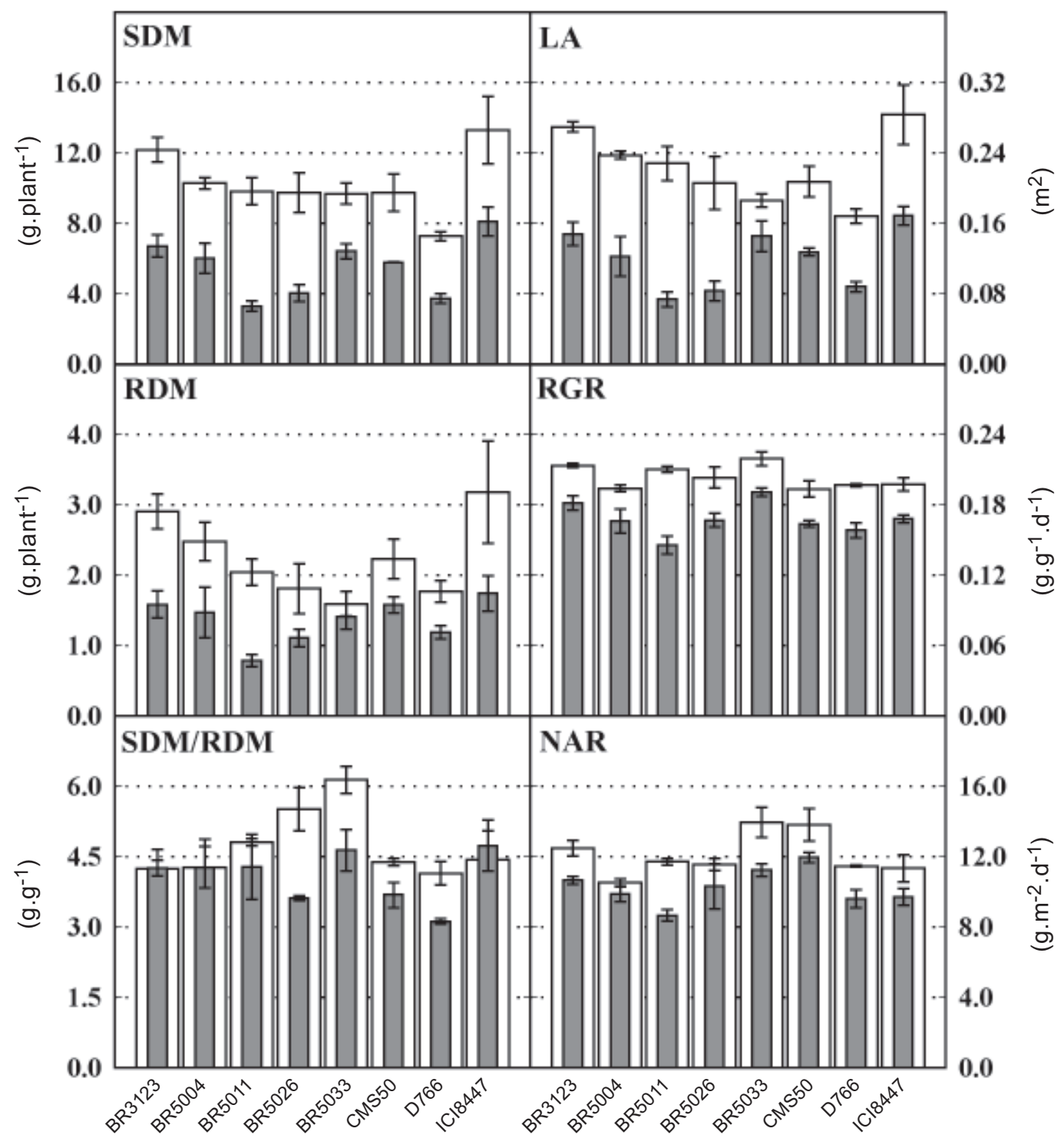

Figure 1. Shoot (SDM) and root (RDM) dry masses, shoot to root dry mass ratio (SDM/RDM), leaf area (LA), relative growth rate (RGR), and net assimilation rate (NAR) of eight maize genotypes grown under control ( $\square$ ) and salt stress ( $\square$ ) conditions. The columns represent the means \pm standard deviation. 
Table 1. Leaf temperature $\left(\mathrm{T}_{l}\right)$, stomatal conductance $\left(\mathrm{g}_{\mathrm{s}}\right)$, transpiration $(\mathrm{E})$ and predawn leaf water potential $\left(\Psi_{\mathrm{w}}\right)$ of eight maize genotypes grown under control and salt stress conditions. Means followed by the same letter signify that control and salt stress treatments are not statistically different according to Tukey's test $(\mathrm{P}<0.05)$, for each of the studied parameters.

\begin{tabular}{|c|c|c|c|c|c|c|c|c|}
\hline \multirow[t]{2}{*}{ Genotype } & \multicolumn{2}{|c|}{$\mathrm{T}_{l}\left({ }^{\circ} \mathrm{C}\right)$} & \multicolumn{2}{|c|}{$\mathrm{g}_{\mathrm{s}}\left(\mathrm{mmol} \cdot \mathrm{m}^{-2} \cdot \mathrm{s}^{-1}\right)$} & \multicolumn{2}{|c|}{$\mathrm{E}\left(\mathrm{mmol} \cdot \mathrm{m}^{-2} \cdot \mathrm{s}^{-1}\right)$} & \multicolumn{2}{|c|}{$\Psi_{\mathrm{w}}(\mathrm{MPa})$} \\
\hline & control & Salt & control & salt & control & salt & control & salt \\
\hline BR3123 & $29.83 b$ & $30.30^{\mathrm{a}}$ & $108.33 \mathrm{a}$ & $63.43 b$ & $3.13 \mathrm{a}$ & $1.92 b$ & $-0.22 \mathrm{a}$ & $-0.49 b$ \\
\hline BR5004 & $29.90 b$ & $30.40^{\mathrm{a}}$ & $123.00 \mathrm{a}$ & $71.27 \mathrm{~b}$ & $3.60 \mathrm{a}$ & $2.16 \mathrm{~b}$ & $-0.24 a$ & $-0.51 b$ \\
\hline BR5011 & $30.30 \mathrm{~b}$ & $30.87^{\mathrm{a}}$ & $99.50 \mathrm{a}$ & $63.37 \mathrm{~b}$ & $3.00 \mathrm{a}$ & $1.99 \mathrm{~b}$ & $-0.34 \mathrm{a}$ & $-0.62 b$ \\
\hline BR5026 & $30.60 \mathrm{~b}$ & $31.03^{\mathrm{a}}$ & $84.80 \mathrm{a}$ & $51.63 b$ & $2.60 \mathrm{a}$ & $1.68 \mathrm{~b}$ & $-0.21 \mathrm{a}$ & $-0.37 b$ \\
\hline BR5033 & $31.37 \mathrm{a}$ & $31.37^{\mathrm{a}}$ & $102.27 \mathrm{a}$ & $90.80 \mathrm{a}$ & $3.26 \mathrm{a}$ & $2.90 \mathrm{a}$ & $-0.29 a$ & $-0.32 \mathrm{a}$ \\
\hline CMS50 & $31.07 \mathrm{a}$ & $31.17^{\mathrm{a}}$ & $92.47 \mathrm{a}$ & $76.80 \mathrm{~b}$ & $2.92 \mathrm{a}$ & $2.43 \mathrm{~b}$ & $-0.15 \mathrm{a}$ & $-0.37 b$ \\
\hline D766 & $30.33 a$ & $30.53^{\mathrm{a}}$ & $83.43 a$ & $54.87 \mathrm{~b}$ & $2.51 \mathrm{a}$ & $1.66 \mathrm{~b}$ & $-0.25 a$ & $-0.40 b$ \\
\hline ICI8447 & $30.53 b$ & $31.60^{\mathrm{a}}$ & $95.93 \mathrm{a}$ & $58.23 \mathrm{~b}$ & $2.92 \mathrm{a}$ & $1.89 \mathrm{~b}$ & $-0.30 \mathrm{a}$ & $-0.45 b$ \\
\hline
\end{tabular}

and this led some authors to suggest that NAR reduction should be a good physiological marker for salt tolerance (Azevedo Neto and Tabosa, 2000a). Our results suggest that this should be used with care. For instance, under control conditions, genotype CMS50 had a NAR identical to that of BR5033, and when both of them were subjected to salt stress the NAR of the former was slightly higher than that of the latter, suggesting that CMS50 should be more salt-tolerant than BR5033. However, their SDM, RDM, LA, and RGR showed exactly the contrary, i.e. BR5033 was more salttolerant than CMS50.

The transpiration and leaf water potential results suggest that the water balance of BR5033 genotype was better adapted to salt stress than that of all other genotypes. It is well known that salt stress reduces root hydraulic conductivity resulting in decreased water flow from roots to shoot, even in osmotically adjusted plants (O'Leary, 1969; Prisco, 1980). This decrease in water flow due to salt stress may cause a lowering in leaf water content, that would result in stomatal closure in order to maintain their water status (Prisco, 1980; Robinson et al., 1997). Therefore, it could be hypothesized that the maintenance of $g_{s}$ and $\Psi_{w}$ in BR5033 was due to the fact that this genotype was much more resistant to a salt induced reduction in root hydraulic conductivity than the others, and as a result maintained its water status even under salt stress conditions.

The higher $\mathrm{Na}^{+}$content in roots than in leaves of salt stressed plants (figure 2) has also been observed for other maize genotypes (Alberico and Cramer, 1993; Erdei and Taleisnik, 1993; Azevedo Neto and Tabosa, 2000b). Based on leaf $\mathrm{Na}^{+}$and water contents it was estimated that the $\mathrm{Na}^{+}$ concentrations in leaves of both BR5011 and BR5033 genotypes were 185 and 177 mmol.L ${ }^{-1}$, respectively. These values are much higher than the cytosolic $\mathrm{Na}^{+}$concentration of $100 \mathrm{mmol}^{-1}$ that is considered as the upper limit for cells adapted or not to salt stress (Binzel et al., 1988). Although the estimated values represent a mean of the $\mathrm{Na}^{+}$concentration in the vacuole and cytoplasm, they may suggest that both BR5011 and BR5033 genotypes compartmentalize ions within their leaf cells (Hajibagheri et al., 1987). Some authors (Alberico and Cramer, 1993) have suggested that salt tolerance in maize was not related to shoot $\mathrm{Na}^{+}$content but to the capacity of the cells to compartmentalize the ions in the vacuole, i.e. maintain a low $\mathrm{Na}^{+}$content in the cytoplasm. Therefore, it is possible that BR5033 was more salt-tolerant than BR5011 because it was more efficient in excluding $\mathrm{Na}^{+}$ from leaf cell cytoplasm.

The reduction in potassium content in both leaves and roots as result of salt stress (figure 2) has been observed previously, and it has been interpreted as resulting from competition between this ion and $\mathrm{Na}^{+}$(Hajibagheri et al., 1987; Alberico and Cramer, 1993; Azevedo Neto and Tabosa, 2000b). The differences in leaf $\mathrm{K}^{+}$content could not explain the differences in salt tolerance between all genotypes. However, the higher reduction in root $\mathrm{K}^{+}$content of the most salt-sensitive genotype suggests that salt induced shoot growth inhibition is mainly due to metabolic changes resulting from ion imbalance or ion toxicity occurring in root system (Prisco, 1980; Munns, 2002).

Soluble amino acids and carbohydrates are considered to be the main organic solutes involved in osmotic adjustment (Ullah et al., 1993; Saneoka et al., 1995; Lacerda et al., 2001). Contrary to the situation in leaves, root soluble organic solutes 


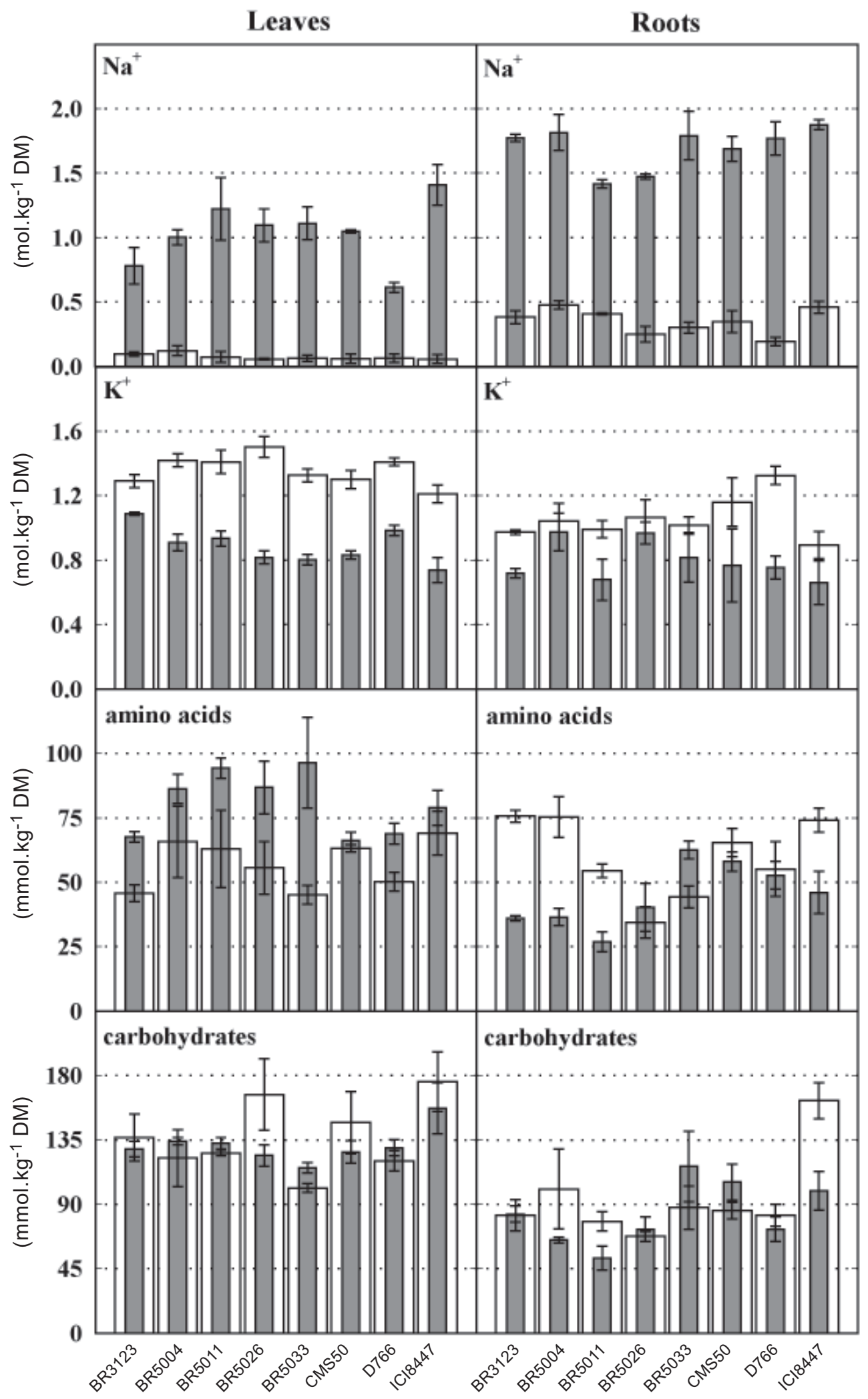

Figure 2. Sodium, potassium, soluble amino acids and soluble carbohydrates in leaves and roots of eight maize genotypes grown under control ( $\square$ ) and salt stress $(\square)$ conditions. The columns represent the means \pm standard deviation. 


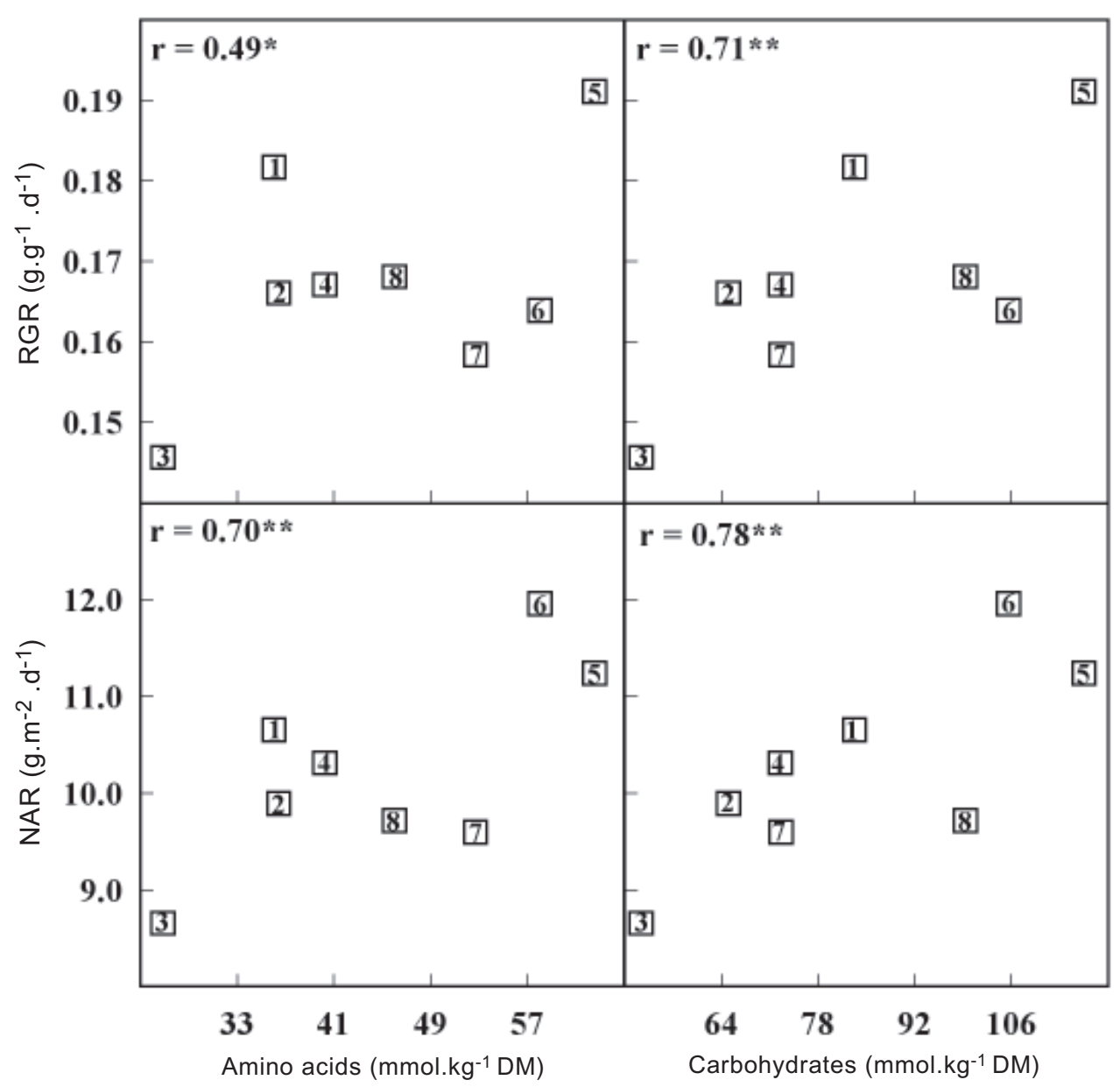

Figure 3. Correlation between soluble amino acids, and soluble carbohydrates in roots versus relative growth rate (RGR) and net assimilation rate (NAR) of eight maize genotypes grown in nutrient solution with added $100 \mathrm{mmol}^{-1} \mathrm{NaCl}^{-} \mathrm{Genotypes}$ BR3123, BR5004, BR5011, BR5026, BR5033, CMS50, D766, and ICI8447 are numbered from 1 to 8 , in that order, $\mathrm{r}=$ correlation coefficient, $*=$ statistically significant $(\mathrm{P}<0.05), * *=$ statistically significant $(\mathrm{P}<0.01)$.

from stressed plants were highly correlated with RGR and NAR (figure 3). The analysis of the correlations between root organic solutes versus RGR and NAR showed that as the root organic solute contents increase the plants tend to be more salt-tolerant.

Under salt stress, the salt-sensitive genotype showed the lowest root $\mathrm{Na}^{+}$content, which could be explained by the lower capacity of the plants to retain sodium in their root cells when they were grown under such conditions (Greenway and Munns, 1980; Boursier and Läuchli, 1990). In addition, the salt-induced depletion of the root soluble organic solute contents in this genotype may be due to the inhibition of net photosynthesis (figure 1), reducing the amount of carbon fixed in the shoot and transported to the roots (Richardson and McCree, 1985). At the same time, the salt-induced soluble organic solute accumulation in roots of the most salt-tolerant genotype (BR5033) may have helped the maintenance of water absorption by the roots and its flux to the shoot. This would also help to conserve its $\Psi_{\mathrm{w}}$ (table 1) and to maintain its net photosynthetic rate and growth at a relatively high level when plants were grown under salt stress conditions. The higher salt-tolerance of BR5033 may also be associated to other factors, such as lower metabolic (energetic) cost spent with osmoregulation and/or an adequate compartmentalization of inorganic solutes in the vacuoles and of organic solutes in the cytosol (Hajibagheri et al., 1987; Sánchez et al., 1998).

The results obtained showed that of all genotypes studied, BR5033 was the most salt-tolerant and BR5011 the most saltsensitive. They also showed that SDM/RDM ratios, leaf $\mathrm{Na}^{+}$ content or leaf soluble organic solute content had no relation with salt tolerance, i.e., they could not be considered as good morpho-physiological markers for salt tolerance. In contrast, sodium and soluble organic solute accumulation in the roots as a result of salt stress appeared to play an important role in 
the acclimation of these genotypes to salt stress, suggesting that they could be used as physiological markers during the screening for salt tolerance.

Acknowledgements: to Conselho Nacional de Desenvolvimento Científico e Tecnológico (CNPq) and Coordenação de Aperfeiçoamento de Pessoal de Nível Superior (CAPES) for financial support.

\section{REFERENCES}

Alarcón JJ, Sanchez-Blanco MJ, Bolarin MC, Torrecillas A (1994) Growth and osmotic adjustment of two tomato cultivars during and after saline stress. Plant Soil 6:75-82.

Alberico GL, Cramer GR (1993) Is the salt tolerance of maize related to sodium exclusion? I. Preliminary screening of seven cultivars. J. Plant Nutr. 16:2289-2303.

Azevedo Neto AD, Tabosa JN (1999) Evaluation of salt tolerance in seedlings of maize cultivars. Pesq. Agrop. Pernamb. 11:17-21.

Azevedo Neto AD, Tabosa JN (2000a) Salt stress in maize seedlings: I. Growth analisys. Rev. Bras. Eng. Agric. Amb. 4:159-164.

Azevedo Neto AD, Tabosa JN (2000b) Salt stress in maize seedlings: II. Distribution of cationic macronutrients and it's relation with sodium. Rev. Bras. Eng. Agric. Amb. 4:165-171.

Benincasa MMP (1988) Análise de crescimento de plantas (noções básicas). FUNEP, Jaboticabal.

Binzel ML, Hess FD, Bressan RA, Hasegawa PM (1988) Intracellular compartmentation of ions in salt adapted tobacco cells. Plant Physiol. 86:607-614.

Bohnert HJ, Shen B (1999) Transformation and compatible solutes. Sci. Hortic. 78:237-260.

Boursier P, Läuchli A (1990) Growth responses and mineral nutrient relations of salt-stressed sorghum. Crop Sci. 30:1226-1233.

Bray EA, Bailey-Serres J, Weretilnyk E (2000) Responses to abiotic stresses. In: Buchanan BB, Gruissem W, Jones RL (eds), Biochemistry and Molecular Biology of Plants, pp.1158-1203. ASPP, Rockville.

Dubois M, Gilles KA, Hamilton JK, Rebers PA, Smith F (1956) Colorimetric method for determination of sugars and related substances. Anal. Chem. 28:350-356.

Erdei L, Taleisnik E (1993) Changes in water relation parameters under osmotic and salt stresses in maize and sorghum. Physiol. Plant. 89:381-387.

FAO (2000) Global network on integrated soil management for sustainable use of salt-affected soils. Available in: http:/ /www.fao.org/ag/AGL/agll/spush/intro.htm.

Gilbert GA, Gadush MV, Wilson C, Madore MA (1998) Amino acid accumulation in sink and source tissues of Coleus blumei Benth. during salinity stress. J. Exp. Bot. 49:107-114.
Greenway H, Munns R (1980) Mechanisms of salt tolerance in non-halophytes. Annu. Rev. Plant Physiol. Mol. Biol. 31:149-190.

Hajibagheri MA, Harvey DMR, Flowers TJ (1987) Quantitative ion distribution within root cells of saltsensitive and salt-tolerant maize varieties. New Phytol. 105:367-379.

Hasegawa PM, Bressan RA, Zhu J-K, Bohnert HJ (2000) Plant cellular and molecular responses to high salinity. Annu. Rev. Plant Physiol. Plant Mol. Biol. 51:463-499.

Lacerda CF, Cambraia J, Cano MAO, Ruiz HA (2001) Plant growth and solute accumulation and distribution in two sorghum genotypes, under $\mathrm{NaCl}$ stress. Rev. Bras. Fisiol. Veg. 13:270-284.

Lira MA, Faris MA, Mafra RC (1982) Soil fertility and fertilizer use research in intercropping systems in Northeast Brazil. Fertil. Plant Nutr. Bull. 5:151-156.

Munns R (2002) Comparative physiology of salt and water stress. Plant Cell Environ. 28:239-250.

O'Leary JW (1969) The effect of salinity on the permeability of roots to water. Israel J. Bot. 18:1-9.

Prisco JT (1980) Alguns aspectos da fisiologia do "stress" salino. Rev. Bras. Bot. 3:85-94.

Richardson SG, McCree KJ (1985) Carbon balance and water relations of sorghum exposed to salt and water stress. Plant Physiol. 79:1015-1020.

Robinson MF, Véry A-A, Sanders D, Mansfield TA (1997) How can stomata contribute to salt tolerance? Ann. Bot. 80:387-393.

Sánchez FJ, Manzanares M, Andres EF, Tenorio JL, Ayerbe L (1998) Turgor maintenance, osmotic adjustment and soluble sugar and proline accumulation in 49 pea cultivars in response to water stress. Field Crops Res. 59:225-235.

Saneoka H, Nagasaka C, Hahn DT, Yang WJ, Premachandra GS, Joly RJ, Rhodes D (1995) Salt tolerance of glycinebetaine-deficient and -containing maize lines. Plant Physiol. 107:631-638.

Sarruge JRS, Haag HP (1974) Análises químicas em plantas. USP-ESALQ, Piracicaba.

Serraj R, Sinclair TR (2002) Osmolyte accumulation: can it really help increase crop yield under drought conditions? Plant Cell Environ. 25:333-341.

Snedecor GW (1956) Statistical methods applied to experiments in agriculture and biology. The Iowa State College Press, Ames.

Ullah SM, Soja G, Gerzabek MH (1993) Ion uptake, osmoregulation and plant-water relations in faba beans (Vicia faba, L.) under salt stress. Die Bodenkultur 44:291-301.

Wahid A, Masood I, Javet I-H, Rasul E (1999) Phenotipic flexibility as marker of sodium chloride tolerance in sunflower genotypes. Environ. Exp. Bot. 42:85-94.

Yemm EW, Cocking EC (1955) The determination of aminoacids with ninhydrin. Analyst 80:209-213. 